ASIMTOT: JURNAL KEPENDIDIKAN MATEMATIKA

Volume 3 Nomor 2, Juni - November 2021, halaman 137 - 150

Tersedia Daring pada https://journal.unwira.ac.id/index.php/ASIMTOT

\title{
MENINGKATKAN HASIL BELAJAR SISWA PADA MATERI KESETARAAN PECAHAN MATA UANG DENGAN MENGGUNAKAN MEDIA UANG
}

\section{IMPROVING THE ACTIVITY AND LEARNING OUTCOMES CURRENCY FRACTION EQUIVALITY MATERIALS BY USING THE MEDIA OF MONEY}

Yuliarmawati Zendrato, Oktofianus Nggadas, Kristoforus Djawa Djong, Wilfridus Beda Nuba Dosinaeng

SD Inpres Rinalolon ${ }^{1,2}$, Universitas Katolik Widya Mandira ${ }^{3,4}$

armayuli80@gmail.com ${ }^{1}$, ot.nggadas@gmail.com ${ }^{2}$,djongdeflores@gmail.com ${ }^{3}$,wilfridusdosinaeng@gmail.com ${ }^{4}$

\begin{abstract}
Abstrak: Penelitian ini merupakan penelitian tindakan kelas yang bertujuan untuk meningkatkan hasil belajar siswa kelas II SDI Rinalolon pada materi kesetaraan pecahan uang dengan menggunakan media uang. Subjek dalam penelitian ini yaitu semua siswa kelas II SDI Rinalolon Tahun pelajaran 2020/2021 yang berjumlah 14 orang. Pelaksanaan penelitian tindakan kelas ini dilakukan melalui dua siklus. Dari hasil penelitian terlihat bahwa hasil belajar yang diperoleh siswa pada test awal 55,36\% siklus satu 67,71\% dan siklus dua 73,57\%. Pada aspek aktivitas siswa, peningkatan lebih terlihat pada aktivitas mengurutkan/menjumlahkan. Pada siklus 2, semua siswa sudah mampu melakukan lebih dari 1 aktivitas dengan benar; ini berbeda dengan pada siklus 1 di mana masih terdapat siswa yang hanya mampu melakukan 1 saja aktivitas mengurutkan/menjumlahkan nilai mata uang dengan benar. Sedangkan Pada aspek kemampuan guru dalam mengelola pembelajaran, ada peningkatan yang terjadi yaitu dari $67,71 \%$ pada siklus 1 dengan kategori baik ke 95,0\% pada siklus 2 dengan kategori sangat baik. Hal ini menunjukkan kemampuan guru meningkat dari siklus 1 ke siklus 2 sehingga dapat disimpulkan bahwa terjadi peningkatan aktivitas siswa siswa pada materi kesetaraan pecahan mata uang di kelas 2 SDI Rinalolon.
\end{abstract}

Kata Kunci: penelitian tindakan kelas, kesetaraan pecahan uang, media pembelajaran

\begin{abstract}
This research is a classroom action research that aims to improve the learning outcomes of class II SDI Rinalolon students on the subject of currency equivalence using money media. The subjects in this study were all students of class II SDI Rinalolon for the academic year 2020/2021, totaling 14 people. The implementation of this classroom action research was carried out in two cycles. From the results of the study, it can be seen that the learning outcomes obtained by students in the initial test were $55.36 \%$ in cycle one $67.71 \%$ and cycle two $73.57 \%$. In the aspect of student activity, the increase was more visible in the activity of sorting/summing. In cycle 2, all students were able to do more than 1 activity correctly; This is different from cycle 1 where there are still students who are only able to do 1 activity of sorting/summing currency values correctly. Meanwhile, in the aspect of the teacher's ability to manage learning, there was an increase from $67.71 \%$ in cycle 1 with good category to $95.0 \%$ in cycle 2 with very good category. This shows the teacher's ability to increase from cycle 1 to cycle 2, so it can be concluded that there is an increase in student activity on the subject of currency denomination equality in grade 2 SDI Rinalolon.
\end{abstract}

Keywords: classroom action research, currency equivalence, learning media

Cara Sitasi: Zendrato, Y., Nggadas, at.all (2021). Meningkatkan Hasil Belajar Siswa Kelas Ii Sdi Rinalolon Pada Materi Kesetaraan Pecahan Mata Uang Dengan Menggunakan Media Uang. Asimtot: Jurnal Kependidikan Matematika, “3”(“2”), “137-150” 
ASIMTOT: JURNAL KEPENDIDIKAN MATEMATIKA

Volume 3 Nomor 2, Juni - November 2021, halaman 137 - 150

Tersedia Daring pada https://journal.unwira.ac.id/index.php/ASIMTOT

Matematika merupakan salah ilmu pengetahuan yang berperan penting dalam kehidupan sehingga perlu dipelajari dan dipahami oleh berbagai kalangan terutama para siswa di sekolah. Mengacu pada Maure, Djong, \& Dosinaeng (2020), tujuan pembelajaran matematika di sekolah yaitu membantu para siswa agar mampu: 1) memahami konsep-konsep matematika; 2) menggunakan penalaran, melakukan manipulasi matematika dalam membuat generalisasi, melakukan pembuktian, atau menjelaskan gagasan-gagasan dan pernyataan-pernyataan matematis; 3) memecahkan masalah-masalah yang meliputi kemampuan memahami masalah, merancang model matematis, menyelesaikan model, dan menafsirkan solusi yang diperoleh; 4) mengkomunikasikan gagasan dengan menggunakan simbol-simbol, tabel, diagram, ataupun media-media lainnya untuk memperjelas masalah; serta 5) memiliki rasa ingin tahu, perhatian dan minat dalam mempelajari matematika, dan percaya diri dalam memecahkan masalah-masalah matematis yang dihadapi.

Pentingnya matematika dalam kehidupan justru bertentangan dengan kenyataan bahwa matematika sering dianggap sebagai mata pelajaran yang sulit oleh siswa. Hal ini didukung oleh Utari, Wardana, \& Damayani (2019) yang menjelaskan bahwa rendahnya hasil belajar matematika di sekolah disebabkan antara lain oleh anggapan bahwa matematika adalah mata pelajaran yang sulit dan membosankan sehingga menurunkan minat belajar siswa. Rendahnya sikap positif siswa terhadap pembelajaran matematika akan berpengaruh terhadap hasil belajar matematika siswa (Mayratih, Leton, \& Uskono, 2019). Sedangkan dari sisi lain, Novitasari (2016) menjelaskan bahwa salah satu penyebab kesulitan belajar matematika siswa yaitu siswa tidak memahami konsep-konsep matematika yang dipelajari (S. I. Leton et al., 2019). Konsep-konsep dalam matematika bersifat koheren dan sistematis sehingga kesulitan dalam memahami suatu konsep akan berakibat pada kesulitan memahami konsep yang lain pada jenjang yang lebih tinggi (Samuel Igo Leton et al., 2020) (Jagom et al., 2020).

Sesuai dengan amanat Permendikbud no 37 Tahun 2018, salah satu konsep yang dipelajari siswa di kelas II Sekolah Dasar yaitu nilai dan kesetaraan mata uang. Pada KD 3.5 tertulis bahwa kompetensi yang diharapkan telah dikuasai oleh para siswa setelah mempelajari konsep ini yaitu para siswa mampu menjelaskan nilai dan kesetaraan pecahan mata uang. Keterampilan yang diinginkan pada KI 4 sehubungan dengan KD ini adalah mengurutkan nilai mata uang serta mendemonstrasikan berbagai kesetaraan pecahan mata uang. Hal ini berkaitan erat dengan kompetensi awal yang harus dimiliki oleh siswa yaitu mampu menjelaskan perkalian dan pembagian yang melibatkan bilangan cacah serta mengaitkannya dengan kehidupan sehari-hari.

Walaupun telah mempelajari konsep perkalian dan pembagian yang melibatkan bilangan cacah dengan baik serta telah mengenal mata uang rupiah yang digunakan dalam kehidupan sehari-hari namun, berdasarkan pengamatan pada pembelajaran 
ASIMTOT: JURNAL KEPENDIDIKAN MATEMATIKA

Volume 3 Nomor 2, Juni - November 2021, halaman 137 - 150

Tersedia Daring pada https://journal.unwira.ac.id/index.php/ASIMTOT

di kelas, para siswa kelas II SDI Rinalolon ternyata belum semuanya dapat menjelaskan nilai dan kesetaraan pecahan mata uang dengan baik. Dari 14 orang siswa di kelas, hanya 4 orang siswa saja yang tampak cukup mahir ketika menjelaskan nilai dan kesetaraan pecahan mata uang sedangkan 10 rang siswa lainnya tampak masih mengalami kesulitan.

Yang menjadi masalah di kelas II adalah pengetahuan siswa yang tidak merata. Pengetahuan dasar tentang matematika dalam hal menghitung (penjumlahan, pengurangan, perkalian dan pembagian) sangat menentukan lancarnya memperoleh pengetahuan selanjutnya. Adanya siswa yang belum mampu dalam matematika dasar juga dapat menghambat siswa lain yang lebih mampu karena guru harus melayani siswa yang belum mampu sehingga mereka agak terabaikan. Guru juga memerlukan waktu yang lebih lama untuk menyelesaikan kegiatan pembelajaran dari yang direncanakan sebelumnya .

Penyebab dari masalah tersebut dapat disebabkan oleh siswa itu sendiri maupun berasal dari guru. Siswa yang belum mampu mungkin belum memiliki motivasi ataupun ketertarikan dalam pembelajaran yang dilakukan. Siswa tersebut mungkin belum terlibat aktif dalam kegiatan pembelajaran. Dari guru, pembelajaran yang dilakukan belum banyak melibatkan siswa. Tugas-tugas yang diberikan guru dalam pembelajaran maupun pekerjaan rumah belum mampu membuat siswa memperoleh pengetahuan secara maksimal.

Upaya peningkatan hasil belajar siswa pada materi nilai dan kesetaraan pecahan mata uang dapat dilakukan melalui penggunaan media pembelajaran. Penggunaan media pembelajaran diharapkan dapat meningkatkan hasil belajar siswa. Suwarno (2016) menjelaskan bahwa menggunakan media dalam proses pembelajaran akan membawa keuntungan antara lain: (1) siswa menjadi lebih termotivasi dalam mempelajari konsep-konsep matematika; (2) konsepkonsep matematika yang abstrak disajikan dalam bentuk konkret sehingga dapat lebih dipahami dan dimengerti, dan dapat ditanamkan pada tingkat-tingkat yang lebih rendah; (3) hubungan antara konsep abstrak matematika dengan benda-benda di alam sekitar akan lebih dapat dipahami.

Penggunaan media dalam kegiatan pembelajaran dapat mengkonkritkan konsep yang abstrak sehingga lebih mudah dipahami oleh siswa. Dengan menggunakan media uang diharapkan aktivitas siswa pada tema 3 sub tema 2 dapat dioptimalkan. Media uang dipilih sebab dekat dengan kehidupan seharihari siswa dan sesuai dengan materi yang dipelajari. Dengan penggunaan media uang diharapkan hasil belajar siswa meningkat dan ketuntasan kelas dapat tercapai.

\section{Metode Penelitian}

Penelitian ini merupakan penelitian tindakan kelas yang bertujuan untuk meningkatkan hasil belajar siswa kelas II SDI Rinalolon pada materi kesetaraan pecahan uang dengan menggunakan media uang. Subjek dalam penelitian ini yaitu semua siswa kelas II SDI Rinalolon Tahun pelajaran 2020/2021 yang berjumlah 14 orang. 
ASIMTOT: JURNAL KEPENDIDIKAN MATEMATIKA

Volume 3 Nomor 2, Juni - November 2021, halaman 137 - 150

Tersedia Daring pada https://journal.unwira.ac.id/index.php/ASIMTOT

Pelaksanaan penelitian tindakan kelas ini dilakukan melalui dua siklus, dmana pada masing-masing siklus terdiri dari 4 tahap penting yaitu: 1) perencanaan tindakan; 2) pelaksanaan tindakan; 3) observasi; dan 4) refleksi. Pada tahap perencanaan tindakan, peneliti menentukan titik fokus peristiwa yang perlu mendapatkan perhatian khusus yaitu mengenai pelaksanaan pembelajaran matematika pada materi kesetaraan pecahan mata uang dengan menggunakan media uang tema 3 kelas II SDI Rinalolon Kabupaten Rote Ndao, kemudian membuat sebuah instrumen penilaian dan pengamatan untuk membantu peneliti merekam fakta yang terjadi selama tindakan berlangsung. Tahap pelaksanaan tindakan dilakukan dalam bentuk pelaksanaan pembelajaran matematika pada materi kesetaraan pecahan mata uang dengan menggunakan media uang tema 3 kelas 2 SDI Rinalolon Kabupaten Rote Ndao, melakukan aktivitas pembelajaran di kelas sesuai dengan skenario pembelajaran yang terdapat pada RPP. Pada tahap observasi dilakukan pengamatan terhadap aktivitas yang dilakukan oleh guru dan siswa pada saat kegiatan pembelajaran di kelas. Pengamat melakukan pengamatan dan mencatat semua hal yang diperlukan dan terjadi selama pelaksanaan tindakan berlangsung. Pengumpulan data ini dilakukan dengan menggunakan kegiatan lembar observasi. Sedangkan tahap refleksi bertujuan untuk mengkaji secara menyeluruh tindakan yang telah dilakukan berdasarkan data yang telah terkumpul, kemudian dilakukan evaluasi guna menyempurnakan tindakan berikutnya. Kegiatan refleksi ini dilakukan oleh peneliti setelah selesai melakukan tindakan untuk menemukan hal-hal yang sudah dan atau belum sesuai dengan rancangan dan mengetahui secara cermat mengenai hal-hal yang masih perlu diperbaiki.

Instrumen yang digunakan dalam penelitian ini yaitu: 1) Tes Hasil Belajar; 2) Lembar Observasi Kemampuan Guru dalam Mengelola Pembelajaran; dan 3) Lembar Observasi Aktivitas Siswa. Untuk mengetahui ketuntasan hasil belajar (kognitif, afektif dan psikomotor), digunakan instrumen Tes Hasil Belajar (THB). Peserta didik dikatakan belajar tuntas jika nilai THB peserta didik adalah $\geq 70$ (Kriteria Ketuntasan Minimal). Nilai THB dapat dihitung dengan menggunakan rumus:

Nilai THB Siswa $=\frac{\text { Jumlah skor yang diperoleh }}{\text { Jumlah skor maksimal }} \times 100$

(Rosna, 2017).

Sedangkan, persentase ketuntasan klasikal dapat dihitung dengan menggunakan rumus:

$$
P=\frac{\text { Jumlah siswa yang tuntas belajar }}{\text { Jumlah seluruh siswa }} \times 100 \%
$$

Suatu kelas dikatakan tuntas secara klasikal jika minimal $75 \%$ siswa tuntas secara individu.

Analisis hasil pengamatan terhadap kemampuan guru dalam mengelola pembelajaran dilakukan dengan menggunakan lembar pengamatan. Persamaan yang digunakan untuk menghitung kemampuan guru dalam mengelola kegiatan pembelajaran yaitu:

Keterangan:

$$
\bar{x}=\frac{S P_{1}+S P_{2}}{2}
$$

$$
\bar{x} \quad \text { : Skor rata-rata dari aspek }
$$




\section{ASIMTOT: JURNAL KEPENDIDIKAN MATEMATIKA}

Volume 3 Nomor 2, Juni - November 2021, halaman 137 - 150

Tersedia Daring pada https://journal.unwira.ac.id/index.php/ASIMTOT

pengamatan $S P_{1}:$ Skor yang diberikan oleh
pengamat 1 untuk setiap aspek pengamatan.

$\mathrm{SP}_{2} \quad$ : Skor yang diberikan oleh pengamat 2 untuk setiap aspek pengamatan.

Untuk kriteria penilaiannya menggunakan skala Likert, seperti pada tabel berikut ini:

Tabel 1. Kriteria Penilaian Pengamatan Kemampuan Guru

\begin{tabular}{|c|c|c|}
\hline $\begin{array}{l}\text { Rentang } \\
\text { Skor }\end{array}$ & Kriteria & Keterangan \\
\hline $1,00-1,99$ & Tidak Baik & $\begin{array}{lr}\text { Jika guru } & \text { dalam } \\
\text { mengelola } & \text { proses } \\
\text { pembelajaran } & \text { tidak } \\
\text { sesuai dengan } & \text { RPP yang } \\
\text { disiapkan }\end{array}$ \\
\hline $2,00-2,99$ & Kurang Baik & $\begin{array}{lr}\text { Jika guru } & \text { dalam } \\
\text { mengelola } & \text { proses } \\
\text { pembelajaran } & \text { kurang } \\
\text { sesuai dengan } & \text { RPP yang } \\
\text { disiapkan }\end{array}$ \\
\hline $3,00-3,49$ & Cukup Baik & \begin{tabular}{lr} 
Jika guru & dalam \\
mengelola & proses \\
pembelajaran & sebagian \\
besar sesuai dengan RPP \\
\multicolumn{2}{l}{ yang disiapkan }
\end{tabular} \\
\hline $3,50-4,00$ & Baik & $\begin{array}{lr}\text { Jika guru } & \text { dalam } \\
\text { mengelola } & \text { proses } \\
\text { pembelajaran } & \text { sesuai } \\
\text { dengan RPP } & \text { yang } \\
\text { disiapkan } & \end{array}$ \\
\hline
\end{tabular}

Tanggapan siswa terhadap proses pembelajaran dapat diketahui dari lembar aktivitas siswa.. Untuk menghitung respon siswa digunakan persamaan:

$$
C I=\frac{\sum I}{\text { Standar }} \times 100 \%
$$

Keterangan :

$$
\begin{array}{ll}
C I & \text { :Capaian indikator/besarnya } \\
& \text { presentase } \\
\sum I & : \text { Total dari setiap skala jawaban }
\end{array}
$$

Standar : Bobot ideal, bobot ideal diperoleh dari jumlah peserta didik dikali skor tertinggi disetiap pernyataan

Kriteria penilaian aktivitas siswa

\begin{tabular}{|c|c|c|}
\hline $\begin{array}{l}\text { Nilai } \\
(\%)\end{array}$ & Kategori & Keterangan \\
\hline $0-20,99$ & Tidak baik & $\begin{array}{lr}\text { Jika aspek yang diamati } \\
\text { (pendahuluan, inti, penutup) } \\
\text { semuanya sangat tidak } \\
\text { sesuai dengan } \\
\text { dilakukan guru }\end{array}$ \\
\hline $\begin{array}{l}21- \\
40,99\end{array}$ & $\begin{array}{l}\text { Kurang } \\
\text { baik }\end{array}$ & $\begin{array}{l}\text { Jika aspek yang diamati } \\
\text { (pendahuluan, inti, penutup) } \\
\text { sebagian tidak sesuai } \\
\text { dengan yang dilakukan guru } \\
\text { tetapi masih dapat diterima }\end{array}$ \\
\hline $\begin{array}{l}41- \\
60,99\end{array}$ & $\begin{array}{l}\text { Cukup } \\
\text { baik }\end{array}$ & $\begin{array}{l}\text { Jika aspek yang diamati } \\
\text { (pendahuluan, inti, penutup) } \\
\text { sebagian besar sesuai } \\
\text { dengan yang dilakukan guru }\end{array}$ \\
\hline $\begin{array}{l}61- \\
80,99\end{array}$ & Baik & $\begin{array}{l}\text { Jika aspek yang diamati } \\
\text { (pendahuluan, inti, penutup) } \\
\text { semuanya sesuai dengan } \\
\text { yang dilakukan guru }\end{array}$ \\
\hline $81-100$ & $\begin{array}{l}\text { Sangat } \\
\text { baik }\end{array}$ & $\begin{array}{l}\text { Jika aspek yang diamati } \\
\text { (pendahuluan, inti, penutup) } \\
\text { semuanya sangat sesuai dan } \\
\text { tepat dengan yang dilakukan } \\
\text { guru }\end{array}$ \\
\hline
\end{tabular}
adalah sebagai berikut:

\section{Tabel 2. Kriteria Penilaian Keaktifan}

Peserta Didik terhadap Pembelajaran

belajar peserta didik, digunakan Analisis skor Gain yang di Normalitas ( $N$-Gain) yang merupakan selisih antara nilai prettest dan posttest untuk menunjukkan hasil belajar siswa sebelum dan sesudah dilaksanakannya pembelajaran. $\mathrm{N}$-Gain dapat dihitung dengan menggunakan rumus:

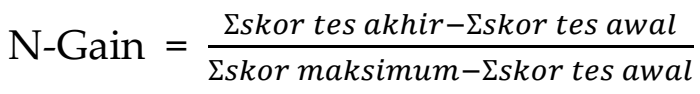




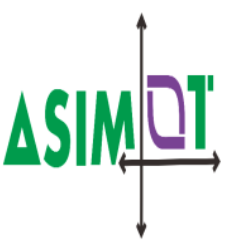

Tabel 3. Kriteria N-Gain

\begin{tabular}{c|c}
\hline $\begin{array}{c}\text { Rentang Indeks } \\
\boldsymbol{N} \text {-Gain }\end{array}$ & Kategori Peningkatan \\
\hline $0,8-1,0$ & Sangat tinggi \\
\hline $0,6-0,79$ & Tinggi \\
\hline $0,4-0,59$ & Sedang \\
\hline $0,2-0,39$ & Rendah \\
\hline $0,0-0,19$ & Sangat rendah \\
\hline
\end{tabular}

\section{Hasil Penelitian dan Pembahasan}

\section{Hasil}

- Pra Siklus

Sebelum melakukan penelitian, peneliti terlebih dahulu mempersiapkan perangkat pembelajaran, antara lain: 1) menyusun RPP; 2) menyusun soal tes (bentuk pilihan ganda 10 butir soal); 3) membuat lembar pegamatan kemampuan guru dalam mengelola pembelajaran berdasarkan aspek-aspek yang ada pada RPP; dan 4) membuat lembar pengamatan aktivitas siswa dalam pembelajaran meliputi kegiatan membandingkan, mengurutkan/ menjumlahkan menggunakan media mata uang. Pada tahap ini juga diskusi antara Peneliti dan pengamat dilakukan untuk menyamakan persepsi antara peneliti dan mitra terhadap aspek-aspek yang diamati baik terhadap guru maupun terhadap siswa.

- Hasil Pelaksanaan Siklus 1

1) Tes Hasil Belajar

Hasil tes belajar pada siklus1 disajikan dalam Tabel 4 di bawah ini.

\section{Tabel 4.Analisis Hasil Belajar Siklus 1}

\begin{tabular}{llcccccc}
\hline & \multicolumn{9}{c}{ Nilai } & & & & \\
\cline { 3 - 5 } No & Siswa & $\begin{array}{c}\text { Tes } \\
\text { Awal } \\
\text { Siklus } \\
\mathbf{1}\end{array}$ & $\begin{array}{c}\text { Tes } \\
\text { Akhir } \\
\text { Siklus }\end{array}$ & Ket & Gain & $\begin{array}{c}\text { N- } \\
\text { Gain }\end{array}$ & Kategori \\
\hline 1 & AK. N & 70 & 70 & T & 0 & 0.00 & Rendah \\
\hline 2 & AP.S & 40 & 45 & TT & 5 & 0.08 & Rendah \\
\hline 3 & DR. B & 65 & 70 & T & 5 & 0.14 & Rendah \\
\hline 4 & EL. M & 40 & 60 & TT & 20 & 0.33 & Sedang \\
\hline 5 & GE. N & 75 & 80 & T & 5 & 0.20 & Rendah \\
\hline 6 & JM. B & 70 & 80 & T & 10 & 0.33 & Sedang \\
\hline 7 & KR.M & 30 & 60 & TT & 30 & 0.43 & Sedang \\
\hline 8 & LS. M & 65 & 70 & T & 5 & 0.14 & Rendah \\
\hline 9 & MD.L & 65 & 70 & T & 5 & 0.14 & Rendah \\
\hline 10 & ME. B & 65 & 70 & T & 5 & 0.14 & Rendah \\
\hline 11 & PA. N & 40 & 70 & T & 30 & 0.50 & Sedang \\
\hline 12 & RD. L & 55 & 68 & T & 13 & 0.29 & Rendah \\
\hline 13 & Sm. F & 30 & 65 & T & 35 & 0.50 & Sedang \\
\hline 14 & Ys. P & 65 & 70 & T & 5 & 0.14 & Rendah \\
\hline Rata-rata & 55.36 & 67.71 & T & 12.35714 & 0.24 & Rendah \\
\hline
\end{tabular}

Berdasarkan Tes Hasil Belajar, dari 14 orang siswa Kelas II, siswa yang tidak tuntas sebanyak 3 orang dan yang tuntas 11orang. Nilai rata-rata pada siklus 1 adalah 67,71 sehingga secara klasikal tuntas. Nilai hasil belajar ini khusus untuk tema 3 kelas II yaitu Tugasku sehari-hari khusus yang berhubungan dengan matematika siswa kelas II SD Inpres Rinalolon pada tema Tugasku sehari-hari mengalami peningkatan dengan nilai gain 0,24 dengan kategori rendah.

Secara ringkas nilai hasil belajar siklus 1 dapat ditampilkan pada Gambar 1 berikut ini.

Siklus 1

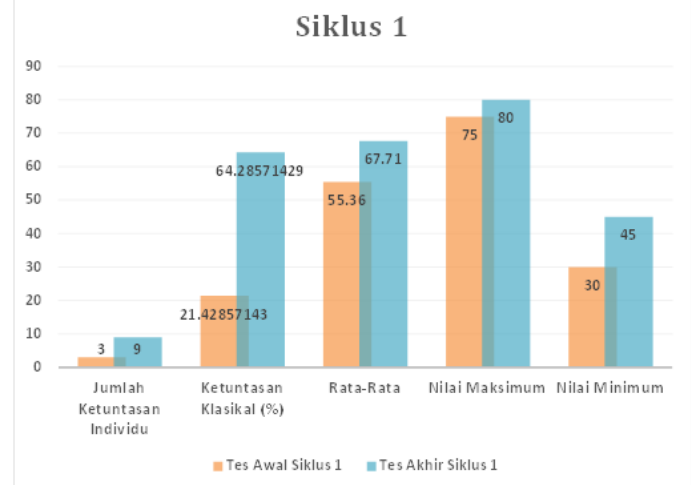

Vol 3. No 2,Juni - November 2021 
ASIMTOT: JURNAL KEPENDIDIKAN MATEMATIKA

Volume 3 Nomor 2, Juni - November 2021, halaman 137 - 150

Tersedia Daring pada https://journal.unwira.ac.id/index.php/ASIMTOT

\section{Gambar 1. Rata-Rata Tes Awal dan Tes Akhir Siklus 1}

Grafik di atas menunjukan hasil belajar siswa Kelas II SDI Rinalolon pada tema Tugasku sehari-hari mengalami peningkatan hasil belajar pada siklus 1 .

2) Aktivitas Siswa dalam Pembelajaran

Hasil pengamatan terhadap aktivitas siswa di Siklus 1 disajikan dalam Tabel 5 di bawah ini.

Tabel 5. Analisis Data Aktivitas Siswa Siklus 1

\begin{tabular}{llllll}
\hline & & \multicolumn{4}{c}{ Pengamat } \\
\cline { 3 - 6 } No & $\begin{array}{c}\text { Aktivitas } \\
\text { Belajar Siswa }\end{array}$ & \multicolumn{5}{c}{ Jumlah Siswa Benar } \\
\cline { 3 - 6 } & & $\mathbf{4}$ & $\mathbf{3}$ & $\mathbf{2}$ & $\mathbf{1}$ \\
\hline A & Membandingkan & 6 & 3 & 4 & 1 \\
\hline \multirow{2}{*}{ B } & $\begin{array}{l}\text { Mengurutkan/ } \\
\text { Menjumlahkan }\end{array}$ & 5 & 4 & 4 & 1 \\
\hline
\end{tabular}

Dari 4 aktivitas membandingkan nilai mata uang yang disiapkan terdapat 6 siswa yang melakukan 4 aktivitas tersebut dengan benar, 3 siswa melakukan 3 aktivitas dengan benar, 4 siswa melakukan 2 aktivitas dengan benar dan 1 siswa yang hanya melakukan 1 aktivitas dengan benar.

Sedangkan dari 4 aktivitas mengurutkan/menjumlahkan nilai mata uang, terdapat 5 siswa melakukan 4 aktivitas tersebut dengan benar, 4 siswa melakukan 3 aktivitas dengan benar, 4 siswa melakukan 2 aktivitas dengan benar dan 1 siswa hanya melakukan 1 aktivitas dengan benar
Secara singkat tabel hasil analisis aktivitas belajar siswa dapat ditampilkan pada grafik di bawah ini.

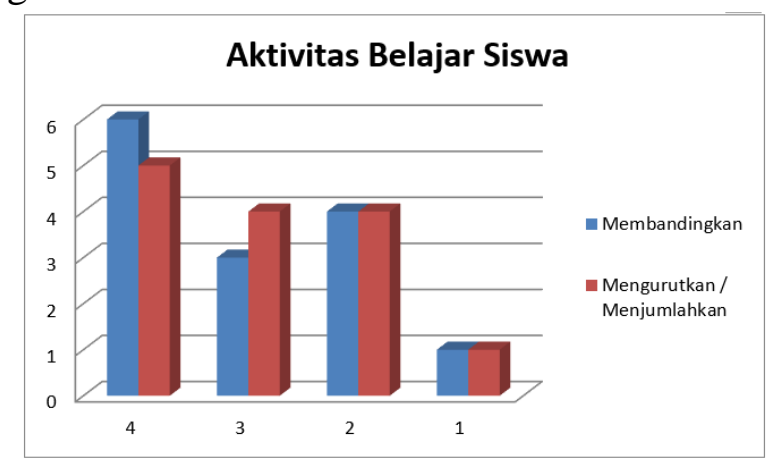

Gambar 2. Aktivitas Belajar Siswa Pada Siklus 1

Pada siklus 1, 13 orang siswa sudah melakukan aktivitas membandingkan, mengurutkan/ menjumlahkan secara optimal, namun masih ada 1 orang siswa yang tidak melakukan aktivitas membandingkan, mengurutkan/ menjumlahkan secara optimal.
3) Kemampuan Guru dalam Mengelola Pembelajaran

Berdasarkan pengisian lembar observasi, Pengamat pertama dan pengamat kedua memberikan nilai yang berbeda, namun terdapat beberapa kesamaan skor penilaian pada aspek langkah-langkah pembelajaran, pengamat memberikan nilai yang cukup obyektif. Hasil analisis menunjukkan bahwa kemampuan guru dalam mengelola pembelajaran terkategori baik namun dengan beberapa aspek yang mendapat skor rendah dari pengamat 1 dan pengamat 2 sebab belum dilakukan oleh peneliti, yaitu: 1) peneliti belum memotivasi siswa untuk mengajukan pertanyaan-pertanyaan tentang uang pecahan; (2) peneliti belum memberikan penguatan dan menuntun para siswa dalam membuat 
ASIMTOT: JURNAL KEPENDIDIKAN MATEMATIKA

Volume 3 Nomor 2, Juni - November 2021, halaman 137 - 150

Tersedia Daring pada https://journal.unwira.ac.id/index.php/ASIMTOT

kesimpulan; serta (3) peneliti belum melakukan refleksi atau membuat rangkuman dengan melibatkan siswa.

Secara rinci, hasil observasi oleh Pengamat 1 dan Pengamat 2 dapat dilihat pada Tabel 6 berikut.

Tabel 6. Analisis Kemampuan Guru dalam Mengelola Pembelajaran Siklus 1

\begin{tabular}{|c|c|c|c|c|}
\hline No & Aspek yang dinilai & Pengamat 1 & Pengamat 2 & Rerata \\
\hline $\mathbf{A}$ & \multicolumn{4}{|l|}{ Pendahuluan } \\
\hline 1 & Mempersiapkan siswa untuk belajar & 1 & 1 & 1 \\
\hline 2 & $\begin{array}{l}\text { Mempersiapkan siswa untuk belajar dan } \\
\text { melakukan apersepsi: Siswa menyanyi } \\
\text { dan berdoa, Guru mengecek kehadiran } \\
\text { siswa, Guru mengumpulkan PR }\end{array}$ & 1 & 1 & 1 \\
\hline B & \multicolumn{4}{|l|}{ Kegiatan Inti } \\
\hline 3 & $\begin{array}{l}\text { Siswa diminta mengamati gambar } \\
\text { pecahan uang }\end{array}$ & 1 & 1 & 1 \\
\hline 4 & $\begin{array}{l}\text { Siswa dimotivasi untuk mengajukan } \\
\text { pertanyaan-pertanyaan tentang uang } \\
\text { pecahan }\end{array}$ & 0 & 1 & 0.5 \\
\hline 5 & $\begin{array}{l}\text { Guru mengenalkan berbagai pecahan } \\
\text { uang logam }\end{array}$ & 1 & 1 & 1 \\
\hline 6 & $\begin{array}{l}\text { Guru meminta beberapa siswa untuk } \\
\text { menuliskan pecahan uang yang lain } \\
\text { dipapan tulis }\end{array}$ & 1 & 1 & 1 \\
\hline 7 & $\begin{array}{l}\text { Guru meyakinkan siswa bahwa semua } \\
\text { memahami dengan mengajukan } \\
\text { pertanyaan umpan balik }\end{array}$ & 0 & 0 & 0 \\
\hline 8 & $\begin{array}{l}\text { Guru memberikan penguatan dan } \\
\text { kesimpulan }\end{array}$ & 1 & 0 & 0.5 \\
\hline C & \multicolumn{4}{|l|}{ Penutup } \\
\hline 9 & $\begin{array}{l}\text { Melakukan refleksi atau membuat } \\
\text { rangkuman dengan melibatkan siswa }\end{array}$ & 0 & 0 & 0 \\
\hline 10 & $\begin{array}{l}\text { Melaksanakan tindak lanjut dengan } \\
\text { memberikan arahan, atau kegiatan, atau } \\
\text { tugas sebagai bagian remedial } \\
\text { pengavaan }\end{array}$ & 1 & 1 & 1 \\
\hline & Jumlah Skor yang Diperoleh & 7 & 7 & 7 \\
\hline & Kriteria & & & Baik \\
\hline
\end{tabular}

\section{4) Evaluasi dan Rencana Tindak Lanjut}

Hasil diskusi antara pengamat dan peneliti terkait kelebihan, peneliti menyiapkan perangkat pembelajaran, mengajar dengan percaya diri, menggunakan media, menerapkan pembelajaran sesuai aspekaspek yang ada pada lembaran pengamatan secara optimal. Adapun kekurangan peneliti tidak menyampaikan beberapa aspek sesuai yang tercantum pada Tabel 6 terlebih pada poin 7 dan 9. Dari hasil evaluasi pengamat satu dan pengamat dua dengan peneliti disepakati bahwa kelemahan yang dilakukan dalam proses pembelajaran sebelumnya perlu diperhatikan untuk diperbaiki pada kegiatan pembelajaran yang akan datang sehingga pembelajaran dilaksanakan secara lebih optimal.

- Pelaksanaan Siklus 2

1) Tes Hasil Belajar

Hasil tes belajar pada siklus1 disajikan dalam Tabel 7 di bawah ini.

Tabel 7.Analisis Hasil Belajar Siklus 2

\begin{tabular}{|c|c|c|c|c|c|c|c|}
\hline \multirow[b]{2}{*}{ No } & \multirow[b]{2}{*}{$\begin{array}{c}\text { Inisial } \\
\text { Siswa }\end{array}$} & \multicolumn{2}{|c|}{ Nilai } & \multirow[b]{2}{*}{ Ket } & \multirow[b]{2}{*}{ Gain } & \multirow[b]{2}{*}{ N-Gain } & \multirow[b]{2}{*}{ Kategori } \\
\hline & & $\begin{array}{c}\text { Tes } \\
\text { Awal } \\
\text { Siklus 2 }\end{array}$ & $\begin{array}{c}\text { Tes } \\
\text { Akhir } \\
\text { Siklus 2 }\end{array}$ & & & & \\
\hline 1 & AK. N & 70 & 80 & $\mathrm{~T}$ & 10 & 0.33 & Sedang \\
\hline 2 & AP.S & 45 & 60 & TT & 15 & 0.27 & Rendah \\
\hline 3 & DR. B & 70 & 75 & $\mathrm{~T}$ & 5 & 0.17 & Rendah \\
\hline 4 & EL. M & 60 & 65 & $\mathrm{~T}$ & 5 & 0.13 & Rendah \\
\hline 5 & GE. N & 80 & 85 & $\mathrm{~T}$ & 5 & 0.25 & Rendah \\
\hline 6 & JM. B & 80 & 85 & $\mathrm{~T}$ & 5 & 0.25 & Rendah \\
\hline 7 & KR.M & 60 & 60 & TT & 0 & 0.00 & Rendah \\
\hline 8 & LS. M & 70 & 70 & $\mathrm{~T}$ & 0 & 0.00 & Rendah \\
\hline 9 & MD.L & 70 & 75 & $\mathrm{~T}$ & 5 & 0.17 & Rendah \\
\hline 10 & ME.B & 70 & 80 & $\mathrm{~T}$ & 10 & 0.33 & Sedang \\
\hline 11 & PA. N & 70 & 75 & $\mathrm{~T}$ & 5 & 0.17 & Rendah \\
\hline 12 & RD. L & 68 & 75 & $\mathrm{~T}$ & 7 & 0.22 & Rendah \\
\hline 13 & Sm. F & 65 & 65 & $\mathrm{~T}$ & 0 & 0.00 & Rendah \\
\hline 14 & Ys. P & 70 & 80 & $\mathrm{~T}$ & 10 & 0.33 & Sedang \\
\hline \multicolumn{2}{|c|}{ Rata-rata } & 67.71 & 73.57 & $\mathrm{~T}$ & 5.86 & 0.19 & Rendah \\
\hline
\end{tabular}

terdapat peningkatan jumlah siswa yang tuntas pada Siklus 2 yaitu sebanyak 12 orang siswa. Rata-rata nilai THB pun mengalami peningkatan dari 67.71 ke 73.57.

Secara visual, peningkatan nilai ratarata siklus 2 dari siklus 1 dapat dilihat pada Gambar 3 berikut ini. 
ASIMTOT: JURNAL KEPENDIDIKAN MATEMATIKA

Volume 3 Nomor 2, Juni - November 2021, halaman 137 - 150

Tersedia Daring pada https://journal.unwira.ac.id/index.php/ASIMTOT

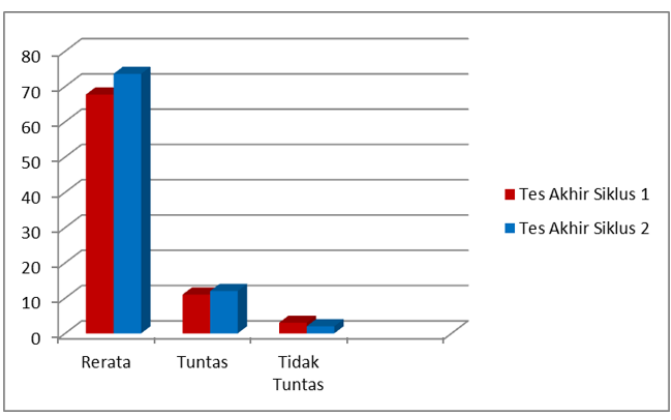

Gambar 3. Rerata Hasil Belajar Siklus 1 dan Siklus 2

2) Aktivitas Siswa dalam Pembelajaran

Hasil pengamatan terhadap aktivitas siswa di Siklus 1 disajikan dalam Tabel 8 di bawah ini.

Tabel 8. Analisis Data Aktivitas Siswa Siklus 2

\begin{tabular}{clllll}
\hline & & \multicolumn{4}{c}{ Pengamat } \\
\cline { 3 - 6 } No & $\begin{array}{l}\text { Aktivitas } \\
\text { Belajar Siswa }\end{array}$ & \multicolumn{3}{c}{ Jumlah Siswa Benar } \\
\cline { 3 - 6 } & $\mathbf{4}$ & $\mathbf{3}$ & $\mathbf{2}$ & $\mathbf{1}$ \\
\hline $\mathrm{A}$ & $\begin{array}{l}\text { Membandingk } \\
\text { an }\end{array}$ & 6 & 2 & 5 & 1 \\
\hline B & $\begin{array}{l}\text { Mengurutkan/ } \\
\text { Menjumlahka } \\
\text { n }\end{array}$ & 6 & 3 & 5 & 0 \\
\hline
\end{tabular}

Pada tabel aktivitas siswa dalam belajar di atas dari hasil pengamat mengatakan bahwa semua siswa mampu membandingkan, mengurutkan/ menjumlahkan nilai mata uang. Dari 4 aktivitas membandingkan nilai mata uang yang disiapkan terdapat 6 siswa yang melakukan 4 aktivitas tersebut dengan benar, 2 siswa melakukan 3 aktivitas dengan benar, 5 siswa melakukan 1 aktivitas dengan benar dan 1 siswa yang hanya melakukan 1 aktivitas dengan benar. Sedangkan dari
4 aktivitas mengurutkan/menjumlahkan nilai mata uang, terdapat 6 siswa melakukan 4 aktivitas tersebut dengan benar, 3 siswa melakukan 3 aktivitas dengan benar, dan 5 siswa melakukan 2 aktivitas dengan benar.

Secara singkat tabel hasil analisis aktivitas belajar siswa dapat ditampilkan dalam bentuk grafik seperti pada Gambar 4 berikut.

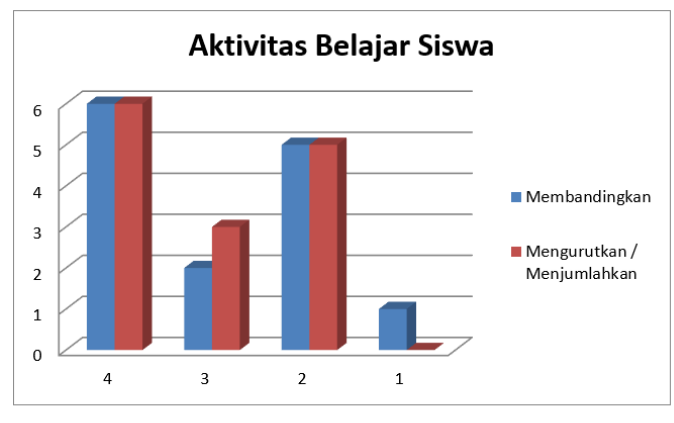

Grafik 4.4 Aktvitas Belajar Siswa Pada Siklus 2

\section{Gambar 4. Aktivitas Belajar Siswa Pada Siklus 2}

3) Kemampuan Guru dalam Mengelola Pembelajaran

Berdasarkan pengisian lembar observasi, Pengamat pertama dan pengamat kedua memberikan nilai yang berbeda juga ada kesamaan pada langkah-langkah pembelajaran, pengamat memberikan nilai yang cukup obyektif. Ada beberapa aspek perbedaan pengamat 1 dan pengamat 2 , pengamat 1 menilai peneliti sudah melakukan semua aspek-aspek pembelajaran yang ada dlam lembar pengamatan sedangkan pengamat 2 ada yang belum dilakukan oleh peneliti, yaitu peneliti belum meyakinkan siswa bahwa semua memahami dengan 


\section{ASIMTOT: JURNAL KEPENDIDIKAN MATEMATIKA}

Volume 3 Nomor 2, Juni - November 2021, halaman 137 - 150

Tersedia Daring pada https://journal.unwira.ac.id/index.php/ASIMTOT

mengajukan pertanyaan tentang uang pecahan.

Berdasarkan hasil analisis tersebut maka kemampuan guru dalam mengelola pembelajaran di Siklus 2 ini tergolong sangat baik. Secara rinci, hasil observasi oleh Pengamat 1 dan Pengamat 2 dapat dilihat pada Tabel 9 berikut.

Tabel 9. Analisis Kemampuan Guru dalam Mengelola Pembelajaran Siklus 2

\begin{tabular}{|c|c|c|c|c|}
\hline No & Aspek yang Dinilai & Pengamat 1 & Pengamat 2 & rerat: \\
\hline & Pendahuluan & & & \\
\hline 1 & Mempersiapkan siswa untuk belajar & 1 & 1 & 1 \\
\hline \multirow[t]{2}{*}{2} & $\begin{array}{l}\text { Mempersiapkan siswa untuk belajar } \\
\text { dan melakukan apersepsi: } \\
\text { menyanyi dan berdoa, Guru } \\
\text { mengecek kehadiran siswa, Guru } \\
\text { mengumpulkan PR }\end{array}$ & 1 & 1 & 1 \\
\hline & Kegiatan Inti & & & \\
\hline 3 & $\begin{array}{l}\text { Siswa diminta mengamati gambar } \\
\text { pecahan uang }\end{array}$ & 1 & 1 & 1 \\
\hline 4 & $\begin{array}{l}\text { Siswa dimotivasi untuk mengajukan } \\
\text { pertanyaan-pertanyaan tentang uang } \\
\text { pecahan }\end{array}$ & 1 & 1 & 1 \\
\hline 5 & $\begin{array}{l}\text { Guru mengenalkan berbagai pecahan } \\
\text { uang logam }\end{array}$ & 1 & 1 & 1 \\
\hline 6 & $\begin{array}{l}\text { Guru meminta beberapa siswa untuk } \\
\text { menuliskan pecahan uang yang lain } \\
\text { dipapan tulis }\end{array}$ & 1 & 1 & 1 \\
\hline 7 & $\begin{array}{lcc}\text { Guru meyakinkan siswa } & \text { bahwa } \\
\text { semua } & \text { memahami } & \text { dengan } \\
\text { mengajukan pertanyaan umpan balik }\end{array}$ & 1 & 0 & 0.5 \\
\hline \multirow[t]{2}{*}{8} & $\begin{array}{l}\text { Guru memberikan penguatan dan } \\
\text { kesimpulan }\end{array}$ & 1 & 1 & 1 \\
\hline & Penutup & & & \\
\hline 9 & $\begin{array}{l}\text { Melakukan refleksi atau membuat } \\
\text { rangkuman dengan melibatkan siswa }\end{array}$ & 1 & 1 & 1 \\
\hline \multirow[t]{4}{*}{10} & $\begin{array}{l}\text { Melaksanakan tindak lanjut dengan } \\
\text { memberikan arahan, atau kegiatan, } \\
\text { atau tugas sebagai bagian remedial } \\
\text { pengayaan }\end{array}$ & 1 & 1 & 1 \\
\hline & Jumlah Skor yang Diperoleh & 10 & 9 & 9.5 \\
\hline & Persentase & $100 \%$ & $90.0 \%$ & $95.0 \%$ \\
\hline & Kriteria & & & $\begin{array}{l}\text { Sanga } \\
\text { Baik }\end{array}$ \\
\hline
\end{tabular}

- Rekapitulasi Pelaksanaan Pembelajaran

1) Rekapitulasi Hasil Belajar

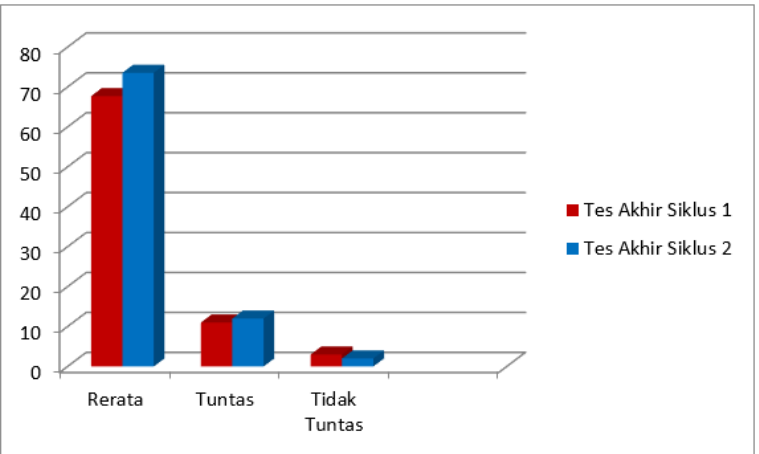

\section{Gambar 5. Rekapitulasi Hasil Belajar Siklus 1 dan Siklus 2}

Dari hasil belajar kelas 2 SD Ipres Rinalolon terjadi peningkatan sebagai berikut: a) Siklus satu Reratanya 67.71Tuntas 11 siswa dan yang tidak tuntas ada 3 siswa; b) Siklus dua Reratanya 73.57 Tuntas 12 siswa dan yang tidak tuntas ada 2 siswa.

2) Rekapituasi Aktivitas Belajar Siswa

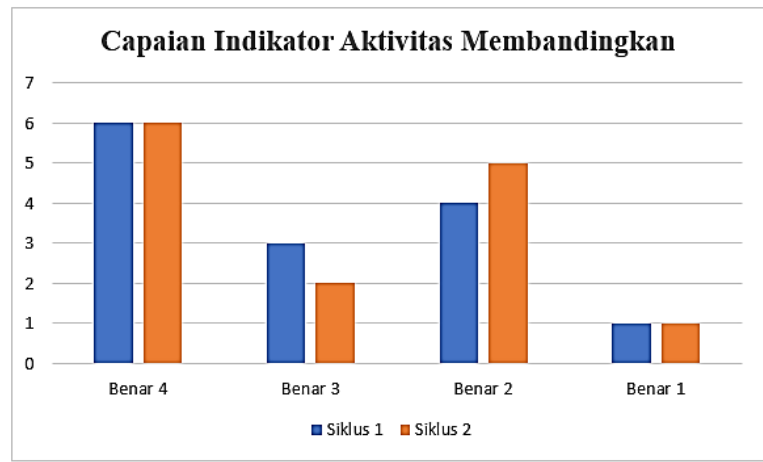

Gambar 6. Rekapitulasi Aktivitas Membandingkan Siklus 1 dan Siklus 2 
ASIMTOT: JURNAL KEPENDIDIKAN MATEMATIKA

Volume 3 Nomor 2, Juni - November 2021, halaman 137 - 150

Tersedia Daring pada https://journal.unwira.ac.id/index.php/ASIMTOT

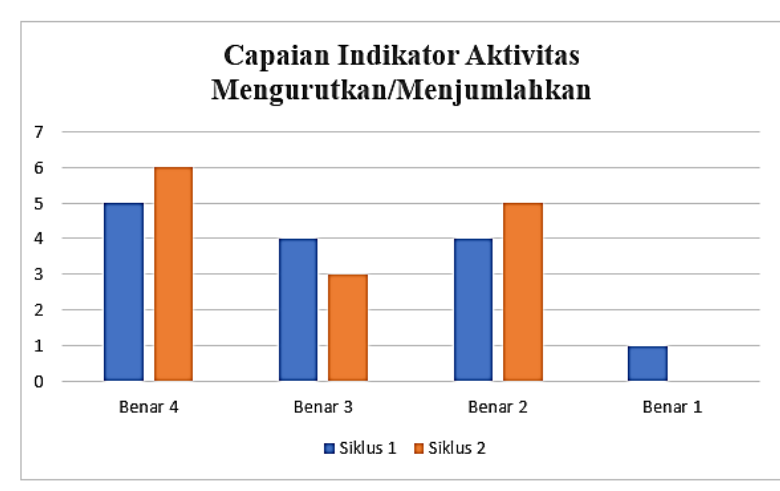

Gambar 7. Rekapitulasi Aktivitas Mengurutkan/Menjumlahkan Siklus 1 dan Siklus 2

Pada grafik aktivitas siswa dalam belajar di atas, dari hasil pengamatan, diketahui bahwa para siswa mampu membandingkan dan mengurutkan/ menjumlahkan nilai mata uang. Pada siklus 2, dari 4 aktivitas membandingkan nilai mata uang yang disiapkan terdapat 6 siswa yang melakukan 4 aktivitas tersebut dengan benar, 2 siswa melakukan 3 aktivitas dengan benar, 5 siswa melakukan 1 aktivitas dengan benar dan 1 siswa yang hanya melakukan 1 aktivitas dengan benar.

Peningkatan aktivitas siswa lebih terlihat pada aktivitas mengurutkan/menjumlahkan. Pada siklus 2, semua siswa sudah mampu melakukan lebih dari 1 aktivitas dengan benar; ini berbeda dengan pada siklus 1 di mana masih terdapat siswa yang hanya mampu melakukan 1 saja aktivitas mengurutkan/menjumlahkan nilai mata uang dengan benar.

3) Rekapitulasi Guru mengelola Pembelajaran

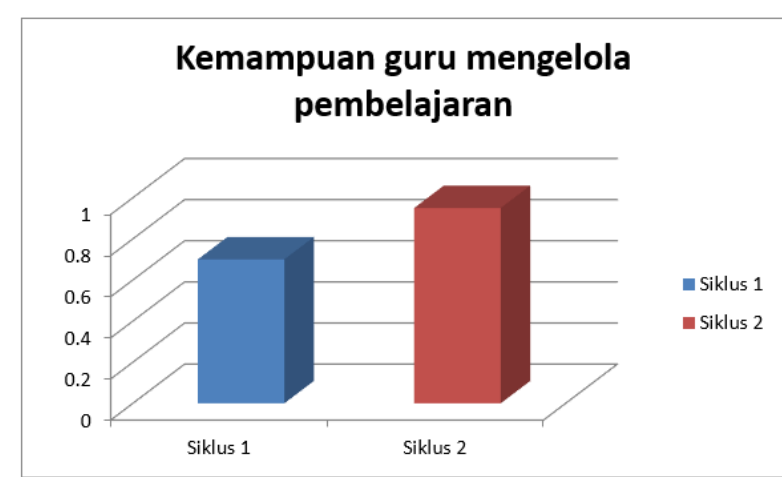

\section{Gambar 8. Rekapitulasi Hasil Pengamatan Kemampuan Guru dalam Mengelola Pembelajaran}

Pada Gambar 8 di atas dapat dilihat bahwa terdapat peningkatan kemampuan guru dalam mengelola pembelajaran dari siklus 1 ke siklus 2. Berdasarkan hasil observasi oleh dua pengamat, kemampuan guru dalam mengelola pembelajaran di kelas telah sesuai dengan langkah-langkah RPP. Jumlah Skor yang diperoleh pada siklus 1 adalah 7, Reratanya 7, dan Ketercapaiannya 70\% (termasuk kategori baik), sedangkan jumlah skor yang diperoleh pada siklus 2 adalah 9.5, Reratanya 9.5, dan ketercapaiannya $95.0 \%$ (termasuk kategori sangat baik).

\section{- Refleksi}

Dari hasil refleksi yang dilakukan dan diskusi betsama pengamat satu dan pengamat dua, dapat dikatakan bahwa dengan menggunakan media uang, aktivitas dan hasil belajar siswa telah meningkat dan ketuntasan kelas telah tercapai. Hanya terdapat dua orang siswa yang belum tuntas, hal ini disebabkan karena siswa tersebut mengalami gangguan perkembangan intelektual. 
SSIM!|i'

\section{Pembahasan}

Hasil belajar yang diperoleh siswa pada tes awal siklus 1 yaitu 55,36\%, tes akhir siklus 1 yaitu $67,71 \%$, dan tes akhir siklus 2 yaitu 73,57\%. Hal ini menunjukkan adanya peningkatan dalam hasil belajar. Dengan menerapkan media uang, hasil belajar siswa dalam membandingkan uang menjadi meningkat. Hal ini disebabkan karena uang asli ditunjukan kepada siswa sehingga siswa cepat mengerti dan menarik minat siswa untuk belajar, sehingga siswa terus berlatih dan akhirnya menghasilkan ketuntasan belajar.

Demikian juga dengan aktivitas belajar siswa dalam belajar terjadi peningkatan dari siklus 1 ke siklus 2. Pada aspek kemampuan guru dalam mengelola pembelajaran hasil peroleh guru pada siklus 1 mencapai $67,71 \%$ sedangkan siklus 2 mencapai 95,0\%. Hal ini menunjukkan kemampuan guru meningkat dari siklus $1 \mathrm{ke}$ siklus 2. Demikian juga siswa perlu belajar baik di sekolah, maupun di rumah dengan bantuan orang tua. Orang tua yang memiliki kesadaran akan pentingnya kemampuan berhitung akan berusaha agar anak-anaknya memiliki kesempatan untuk belajar berhitung.

Dalam penelitian tindakan kelas yang dilakukan, hasil yang dicapai telah memenuhi kriteria keberhasilan siklus, sehingga siklus dapat dihentikan. Penerapan media uang terbukti dapat meningkatkan kemampuan aktivitas dan hasil belajar siswa.

\section{Simpulan dan Saran}

\section{Simpulan}

Dari hasil penelitian terlihat bahwa Hasil belajar yang diperoleh siswa pada test awal $55,36 \%$ siklus satu $67,71 \%$ dan siklus dua $73,57 \%$. Hal ini menunjukkan adanya peningkatan hasil belajar siswa pada materi kesetaraan pecahan mata uang di kelas 2 SDI Rinalolon.

Pada aspek aktivitas siswa, peningkatan lebih terlihat pada aktivitas mengurutkan/menjumlahkan. Pada siklus 2, semua siswa sudah mampu melakukan lebih dari 1 aktivitas dengan benar; ini berbeda dengan pada siklus 1 di mana masih terdapat siswa yang hanya mampu melakukan 1 saja aktivitas mengurutkan/menjumlahkan nilai mata uang dengan benar.

Pada aspek kemampuan guru dalam mengelola pembelajaran hasil peroleh guru pada siklus 1 mencapai $67,71 \%$ sedangkan siklus 2 mencapai 95,0\%. Hal ini menunjukkan kemampuan guru meningkat dari siklus 1 ke siklus 2. Sehingga dapat disimpulkan bahwa terjadi peningkatan aktivitas siswa siswa pada materi kesetaraan pecahan mata uang di kelas 2 SDI Rinalolon.

\section{Saran}

Berdasarkan kesimpulan di atas maka peneliti menyarankan kepada setiap guru dalam melakukan pembelajaran, hendaknya menggunakan media pembelajaran untuk membantu para siswanya mempelajari konsep-konsep matematika. Selain itu, untuk 


\section{ASIMTOT: JURNAL KEPENDIDIKAN MATEMATIKA}

\section{Volume 3 Nomor 2, Juni - November 2021, halaman 137 - 150}

Tersedia Daring pada https://journal.unwira.ac.id/index.php/ASIMTOT

mengaktifkan siswa, sebaiknya selalu melibatkan siswa dalam contoh-contoh nyata kehidupan sehari-hari.

\section{Daftar Pustaka}

Dimyati \& Mujiono, (2006). Belajar dan Pembelajaran. Jakarta: Rineka Cipta

Djamarah, B, S. (1996). Psikologi Belajar. Bandung: Rineka Cipta

Hamalik, O. 2007. Proses Belajar Mengajar. Jakarta : Bumi Aksara

Hamalik, O .(2007). Kurikulum Dan Pembelajaran, Jakarta: PT. Bumi Aksara

Khafid, M., \& Suyati. 2004. Media-media Pembelajaran. Jakarta: CV. Pustaka Ilmu

Jagom, Y. O., Uskono, I. V., \& Leton, S. I. (2020). Students' creative thinking in solving geometry problems. Journal of Physics: Conference Series, 1657(1). https://doi.org/10.1088/17426596/1657/1/012076

Leton, S. I., Wahyudin, \& Dosinaeng, W. B. D. (2019). Hearing-impaired student ability to solve the problem in math. Journal of Physics: Conference Series, 1321(2). https://doi.org/10.1088/17426596/1321/2/022111

Leton, Samuel Igo, Djong, K. D., Uskono, I. V., Dosinaeng, W. B. N., \& Lakapu, M. (2020). Profile of Elementary School Teacher in Concept Understanding of Geometry. Infinity Journal, 9(2), 133. https://doi.org/10.22460/infinity.v9i2.p1 33-146

Novitasari, D. (2016). Pengaruh penggunaan multimedia interaktif Terhadap kemampuan pemahaman Konsep matematis siswa. Fibonacci: Jurnal Pendidikan Matematika \& Matematika,
2(2), $8-18$

Martinus, Y. (2007). Kiat Membelajarkan Peserta Didik. Jakarta: PT Gaung Persada Pers.

Maure, L, Y., Djong, D, K., \& Dosinaeng, N, B, W. (2020). Analisis Pemahaman Konsep Matematik Siswa Sma Pada Materi Program Linear. Asimtot: Jurnal Kependidikan Matematika. 2(1), $47-56$

Mayaratih, E, G., Leton, I, S., \& Uskono, V, I. (2019). Pengaruh Disposisi Matematis Terhadap Kemampuan Pemecahan Masalah Matematis Siswa. Asimtot: Jurnal Kependidikan Matematika. 1(1), 41 - 49

Parwata, S, V., Tastra, K, D., \& Kusmayiyatni, N. (2016). Penerapan Model Quantum Berbasis Lingkungan untuk Meningkatkan Kreativitas dan Hasil Belajar IPA Siswa Kelas V. eJournal PGSD Universitas Pendidikan Ganesha. 4(1), 1 - 10

Rayandra Asyar. (2012). Kreatif Mengembangkan Media Pembelajran. Jakarta: Gaung Persada Press.

Rosna, A. (2017). Meningkatkan Hasil Belajar Siswa Melalui Pembelajaran Kooperatif Pada Mata Pelajar IPA di kelas IV SD Terpencil Bainaa Barat. Jurnal Kreatif Tadulako, 4 (6), 235 246

Rudi, S., \& Cepi, R. (2008). Media Pembelajaran. Bandung: Jurusan Kurtekpend FIP UPI.

Rusman. (2012). Belajar dan Pembelajaran Berbasis Komputer Mengembangkan Profesionalisme Guru Abad 21. Bandung: ALFABETA . (2013). Belajar dan Pembelajaran Berbasis Komputer.Jakarta: ALFABETA 


\section{ASIMTOT: JURNAL KEPENDIDIKAN MATEMATIKA}

Volume 3 Nomor 2, Juni - November 2021, halaman 137 - 150

Tersedia Daring pada https://journal.unwira.ac.id/index.php/ASIMTOT

Sardiman. (2010). Interaksi dan Motivasi Belajar Mengajar. Jakarta: Raja Grafindo Persada.

Slameto. (2010). Belajar dan Faktor-Faktor yang Mempengaruhi. Jakarta: Rineka Cipta

Sujana, N. (2009). Penilaian Hasil Belajar. Bandung: PT Rosdakarya

Suwarno. (2016). Meningkatkan Hasil Belajar Siswa Kelas VI SD Negeri 22 Kepahiang dalam Menentukan Volume Bangun Ruang Melalui Penggunaan Alat Praga Kubus Satuan. Jurnal PGSD: Jurnal Ilmiah Pendidikan Guru Sekolah Dasar, 9 (2), 267-276

Utari, R, D., Wardana, S, Y, M., \& Damayani, T, A. (2019). Analisis Kesulitan Belajar Matematika dalam Menyelesaikan Soal Cerita. Jurnal Ilmiah Sekolah Dasar. 3 (4), 534 540

Wibawa, B., \& Mukti, F. (2001). Media Pengajaran. Bandung: CV Maulana 